\title{
TITLE:
}

\section{INVERTEBRATE FAUNA OF THE INTERTIDAL ZONE OF THE TOKARA ISLANDS - III. ECHIUROIDEA AND SIPUNCULOIDEA-}

\author{
$\operatorname{AUTHOR}(\mathrm{S})$ : \\ Tokioka, Takasi
}

\section{CITATION:}

Tokioka, Takasi. INVERTEBRATE FAUNA OF THE INTERTIDAL ZONE OF THE TOKARA ISLANDS - III. ECHIUROIDEA AND SIPUNCULOIDEA-. PUBLICATIONS OF THE SETO MARINE BIOLOGICAL LABORATORY 1953, 3(2): 140-140

ISSUE DATE:

1953-12-20

URL:

http://hdl.handle.net/2433/174476

RIGHT: 


\title{
INVERTEBRATE FAUNA OF THE INTERTIDAL ZONE OF THE TOKARA ISLANDS \\ III. ECHIUROIDEA AND SIPUNCULOIDEA ${ }^{12}{ }^{2}$ )
}

\author{
TAKASI TOKIOKA
}

Seto Marine Biological Laboratory, Sirahama

\section{ECHIUROIDEA}

1. Ochetostoma erythrogrammon LEUCKART \& RÜPPELL

An individual was found in the sand of a pocket zone in the reef of Takarazima. (TK. No. 1). ${ }^{3}$ )

The northern limit of distribution in Japan: Hokkaido.

\section{SIPUNCULOIDEA}

\section{Siphonosoma cumanense (KEFERSTEIN)}

This sipunculid is commonly found in Takarazima in the sandy area on the reef. In Nakanosima, I could find only an individual in the sand. The northern limit of distribution in Japan: Aomori-ken. (TK. Nos. 2-3).

\section{Phascolosoma albolineatum (BAIRD)}

Numerously boring in the reef in the purplish-brownish zones of Takarazima and Nakanosima. The northern limit of distribution in N.W. Pacific: the southern coast of Tyôsen. (TK. Nos. 4-5).

\section{Phascolosoma scolops (SELENKA \& DE MAN)}

Found with the preceding species in both Takarazima and Nakanosima, although much rarer than $P h$. albolineatum. The northern limit of distribution in Japan: Hokkaido. (TK. Nos. 6-7).

1) Scientific Survey of the Tokara Islands, Report No. 4.

2) Contributions from the Seto Marine Biological Laboratory, No. 210.

3) Registered number of the Tokara collections preserved in the museum of the Seto Marine Biological Laboratory.

Publ. Seto Mar. Biol. Lab., III (2), 1953. (Article 11) 